\title{
DID EGYPT SATISFY PREREQUISITES FOR AN IT REGIME?
}

\author{
Ibrahim L. Awad
}

\section{Introduction}

A recent survey by the IMF assumed that the trend towards the adoption of an Inflation Targeting (IT) regime by the emerging market economies is continuing. Over one half of the 88 non-industrial countries covered by this survey expressed a desire to move to explicit or implicit quantitative inflation targets and nearly three quarters of these countries envisaged a shift to full-fledged inflation targeting by 2010 (Batini et al., 2006, pp. 7-8).

Egypt, according to the aforementioned survey, is one of the prospective candidates to switch the monetary policy regime to an IT regime in the short term (1-2 years). Also, the Central Bank of Egypt (CBE) has announced on several occasions its intention to adopt an IT regime as a framework for its monetary policy once the fundamental prerequisites are met (IMF, 2007; CBE, 2005). Moreover, the CBE (2007) stated that it is currently applying implicit inflation targets which will be announced once the CBE completes building up its inflation targeting framework in coordination with the IMF' ${ }^{1}$.

To date, the CBE has not matched its words with deeds. On the one hand, it has not confessed in any degree of detail about which prerequisites are still unfulfilled. On the other hand, the steps taken by the CBE to apply the IT regime are still unsatisfactory².

The purpose of this study is to answer the question 'Is Egypt ready to adopt/apply an IT regime?' The study presumes that a country is ready to apply an IT regime once the prerequisites for an IT regime are satisfied. To explore this presumption in the case of Egypt, the study intends to answer the following questions: (i) what are the prerequisites for an IT regime?; (ii) did emerging market economies satisfy the IT prerequisites in the early days of their adoption of IT regimes?; and (iii) comparing the current position of Egypt to the emerging market economies in the early days of their adoption of IT regimes, has Egypt satisfied the prerequisites for an IT regime? Given the willingness to adopt an IT regime, we assume that a country will adopt/apply an IT regime once it becomes ready for it.

* Institute of Economic Studies, Charles University, Prague (ibrahim@fsv.cuni.cz).

This paper comes under the Institutional Support by the Department of Education MSMT 0021620841

1 This statement by the CBE was in the context of its response to the critique of the Morgan Stanley report, published on March 28, 2007, about the government, specifically the prime minister, overriding the decision making process inside the CBE.

2 The CBE has not yet publicized a precise inflation target, and lacks the internal capacity for measuring and forecasting inflation on a regular basis. There have also been delays by the Central Agency for Public Mobility and Statistics (CAPMAS) in producing a reliable consumer price index (Oxford Analytica, 2005, p. 107). 
This paper is organised as follows: Section 2 defines an IT regime. Section 3 reviews the literature regarding the prerequisites for an IT regime. Section 4 subtracts the lessons from the experience of some emerging market economies including the Czech Republic, Poland and Brazil. Section 5 answers the question to what extent Egypt has satisfied the prerequisites of the IT regime. Section 6 concludes.

\section{Definition of an IT regime}

An IT regime is a framework for monetary policy in which price stability is the primary goal for the monetary policy ${ }^{3}$. Within the IT regime, the central bank (CB) is committed to achieving a publicly announced target for the inflation rate, typically at a mediumterm horizon of one to three years (Bernanke \& Woodford, 2005, p. 1). According to Mishkin (2000), Mishkin and Schmidt-Hebbel (2001), and Schmidt-Hebbel and Tapia (2002), an IT regime encompasses five main elements: (i) a public announcement of medium-term numerical targets for inflation; (ii) an institutional commitment to price stability as a primary goal of the monetary policy; (iii) an information inclusive strategy in which many variables, not just monetary aggregates or the exchange rate, are used for deciding the setting of policy instruments; (iv) increased transparency of the monetary policy strategy through communication with the public and the markets about plans, objectives, and decisions of the monetary authorities; and (v) increased accountability of the $\mathrm{CB}$ for attaining its inflation targets.

\section{Prerequisites for an IT regime}

There is considerable debate among economists about the prerequisites/preconditions that a country has to meet before adopting an IT regime. This debate reflects the fact that there is no generally agreed set of preconditions.

Preconditions that are frequently desirable by most economists (Khan 2003, p. 10; Truman, 2003, p. 49; Batini et al., 2006, p. 18; Jonas \& Mishkin 2003, p. 6) include the following: (i) a commitment to price stability as the primary goal of the monetary policy; (ii) central bank independence; (iii) macroeconomic stability; (iv) a healthy financial system; (v) transparency of the monetary policy and accountability of the central bank; (vi) absence of fiscal dominance; and (vii) institutional elements, including determining monetary policy transmission mechanisms, inflation forecasting, and coordination between the monetary and fiscal policies.

Nevertheless, there is no agreement among economists regarding the question whether the prerequisites have to be met prior to the adoption of an IT regime in an emerging market economy? Eichengreen et al. (1999) argue that emerging market

3 Alan Greenspan reportedly once defines price stability as a rate of inflation so low that private sector do not have to take into account in making economic decisions. A strict definition of price stability suggests an inflation rate at or very near zero. Despite the change in the CPI is widely used to measure the inflation rate the CPI may involve some bias. That is why some economists indicate that targeting the rate of inflation at zero may create serious problems. These problems refer to the fact that both inflation and deflation have negative impact on the economic activity. IT from this perspective is designed for achieving price stability (fighting both inflation and deflation) through hitting a target of inflation (Bernanke, Ben S., et al., 1999, pp. 28-30). 
economies severely lack the technical capabilities and autonomous central banks. Consequently, these countries will be better off with conventional monetary policy frameworks, e.g., targeting exchange rates or targeting monetary aggregates. But Carare et al. (2002) think that the absence of some of the preconditions should not preclude the adoption of IT, especially when policies are being introduced to establish them in the short or medium-term. Truman (2003) thinks of preconditions as part of "full-fledged" inflation targeting that may follow a transitional period. Assessing the role of the "preconditions" for adopting IT, Batini et al. (2006, p. 176) found that no inflation-targeting central bank had all "preconditions" in place prior to the adoption of IT.

Three basic elements are usually highlighted in the vast majority of the literature as the crucial prerequisites for an IT regime. These elements are as follows.

\subsection{Factual (de facto) independence of the central bank ${ }^{4}$}

Central bank independence has to be de facto and not only de jure. Full legal independence of the CB (goal independence and instrument independence) is a controversial issue among economists but factual instrument independence of the $\mathrm{CB}$ is an indispensable requirement as a precondition for a successful application of IT. The CB should be free to choose the appropriate tools and change them whenever it is necessary without any pressures from the government. Also, the CB should have the techniques and technicians to achieve its objectives without substantial outside interference. That is, inflation targets and their tolerance intervals may be formulated by the government and delivered to the $\mathrm{CB}$, which becomes responsible for achieving them. In the course of achieving inflation targets, the CB should not seek or take instructions from any other body. Therefore, the existence of government representatives on the Monetary Policy Committee (MPC) as voting members should be prohibited.

Importantly, with fiscal dominance CB independence is not factual even though the $\mathrm{CB}$ enjoys both legal instrument independence and non-existence of government representatives on the MPC. The existence of fiscal dominance will make it risky for any country to adopt an IT regime ${ }^{5}$. The most visible version of fiscal dominance is the formal obligation of the CB to finance budget deficits ${ }^{6}$.

Masson et al. (1998), Debelle et al. (1998) and Khan (2003) add another dimension in that the shallowness of a capital market is also a common indication of fiscal

4 Several studies stress this point in relation to the meaning of this paper; see Truman (2003, pp. 49-52), Masson et al. (1998, p. 35), Batini et al. (2006, p. 18), Debelle et al. (1998 pp. 11-13), Fraga et al. (2003, pp. 24-25), and Mishkin and Schmidt-Hebbel (2001, p. 5).

5 Fiscal dominance is a situation in which monetary policy is dominated by the financial needs of the government. The connection between the factual independence of the central bank and fiscal dominance is often presented as follows: if the government does not have sufficient resources to finance its operations in the economy and systematically and significantly requires amounts of finance to meet its obligations, then a country's fiscal requirements are likely to dominate and determine the central bank's operations. In such a case, the CB will not be able to achieve its inflation target or keep it inside a determined path (Khan 2003).

6 In a previous study on the political pressure on CBs in emerging market economies, we evaluated the de facto independence of a CB in terms of the ability of the CB to keep its target of monetary supply despite the government's pressures for higher credit. We found that the Central Bank of Egypt (CBE) could not keep the target of monetary supply, and such a failure refers to fiscal dominance (Awad, 2008). 
dominance. On the one hand, a weak financial system may prevent the CB from using interest rates freely to return inflation forecasts to the intended path. That is because a fragile financial system is likely to be unable to afford an increase of nominal interest rates associated with the $\mathrm{CB}$ moping up the liquidity that has been provided at the previous discount window. On the other hand, the financial system is often a by-product of government schemes to extract revenues using various forms of financial repression (interest rate ceiling, high reserve requirements, selective interest rates, and compulsory placement of public debt). In such circumstances, the CB may resist an increase in the market interest rates to correct deviations of forecasted inflation from the target because of the potential impact on the fiscal position. A related argument is that if the cost of bailing out a weak banking system becomes a large fiscal burden, it may lead to fiscal dominance (Truman, 2003, p. 52). However, with reasonably effective monetary policy instruments, e.g. an overnight interest rate and open-market operations, the CB will be able to follow its target more efficiently.

To sum up, the factual independence of a CB rests on three basic pillars: (i) legal instrument independence of the $\mathrm{CB}$; (ii) nonexistence of government representatives on the MPC as voting members; and (iii) absence of fiscal dominance including no obligation for the CB to finance budget deficits, while domestic financial markets should have enough depth to absorb placements of public debt such as treasury bills.

\subsection{Commitment to price stability as a primary goal of monetary policy}

The CB should not target any other variables, e.g. exchange rate or employment. On the one hand, the monetary policy under the commitment to other targets will be confined with those targets and, as a result, the monetary authority is more likely to fail in achieving the announced inflation target. On the other hand, the public will have no assurance that the monetary authorities will give the inflation targets a priority. Such a situation is likely to deteriorate individuals' expectations about the future inflation path because of the uncertainty concerning the credibility of the announced target. Nevertheless, the CB should intervene to prevent undesirable effects of the change in other macroeconomic variables on the future inflation path (Khan, 2003, p. 10).

The commitment to price stability as a primary goal of monetary policy requires some degree of accountability for the $\mathrm{CB}$ concerning implementation of inflation targets. The lessons from the international experience as indicated by Bernanke et al. (1999, p. 38, p. 296) delivered two forms of accountability: firstly, by comparing inflation outcomes with the targets; and secondly, by the CB's obligation to provide the public with a convincing rationale for the policy choices it makes. Given that inflation responds to policy after some lags and inflation targets are rarely hit exactly in the short term, the second form has become the only alternative for maintaining accountability. Practically, many CBs prefer to be more transparent and credible to the public by announcing escape clauses, i.e., exceptions from the obligation to fulfill the inflation target. This explains, on the one hand, why accountability of CBs is less formalized in practice and, on the other hand, why a transparent monetary policy is so important not only as a device to tie down individuals' expectations around an announced inflation target but also as a means of accountability of CBs to the public. 
To sum up, a commitment to price stability requires two basic elements: (i) a CB should not target any other variables than the rate of inflation; and (ii) a CB should be transparent to the public about the exemptions of its inflation target. That is, a CB should announce escape clauses for its inflation target. Such a transparency is a practical device to make a CB accountable to the public in achieving the inflation target.

\subsection{Forecasting capabilities}

Because of time lags between the change of monetary policy instruments and their associated effects on inflation, an IT regime has to be pursued in a forward-looking manner where the current adjustment of monetary policy instruments has to be established on a systematic assessment of the future path of inflation. Consequently, the adoption of an IT regime by announcing some targets for inflation to be achieved in the future and the way to proceed towards achieving such targets requires (Debelle et al., 1998, pp. 3-4): (i) a model for inflation forecasting and inflation projections has to be set up in advance; (ii) the CB has to have a clear idea about its monetary policy transmission mechanisms and the associated lags; and (iii) a high-quality inclusive and updated database of the economic variables has to be available.

\section{Lessons from the experience of some emerging market economies}

Appendix 1 outlines the experience of some emerging market economies including the Czech Republic, Poland and Brazil (henceforth, CPB) ${ }^{7}$. It stresses mainly the following dimensions: (i) the factors behind the decision to adopt an IT regime in each country; (ii) the level of legal independence granted to the $\mathrm{CB}$ and whether there was a legal obligation for the CB to finance budget deficits; (iii) the commitment to price stability as a primary goal of monetary policy, the price index used to formulate and gauge inflation targets, and the reaction of the CB to supply shocks; and (iv) the level of knowledge for both inflation forecasting and monetary policy transmission mechanisms.

Different lessons may be subtracted from the experience of these countries under the adoption of IT as a framework for their monetary policy regimes:

4.1 These countries were seriously keen on and willing to achieve the goal of price stability. The real intention to achieve the goal of price stability was the stimulus behind the preparation for the adoption of IT regimes in these countries. As the intention was real, it was swiftly translated into tangible steps on the ground. From the Brazilian experience, when the BCB and the government became convinced of the adoption of IT as a means to achieve the goal of price stability, the preparation and the switching to the IT regime occurred in a very limited period of time: between March and June 1999. Until the beginning of March 1999, the BCB was not granted formal instrument independence, the forecasting capabilities were very limited, and the majority of the BCB staff did not even know what an IT regime was (see Appendix 1).

7 Appendix 1 includes extended details about the experience of the Czech Republic, Poland, and Brazil. It is available upon request. 
4.2 IT was adopted to serve as a new nominal anchor for monetary policy. After floating their currencies, the CPB found that an IT regime is the only available alternative in order to achieve the goal of price stability on a forward-looking basis. On the one hand, a monetary policy regime without an explicit nominal anchor was not an appropriate alternative for tying down individuals' expectations about the future path of inflation where CBs in these countries did not have a track record of credibility. On the other hand, a monetary targeting regime was neither an appropriate alternative especially after the liberalization of the capital flows and financial markets, which undermined the relationship between the money supply and the price levels.

Why had the CPB floated their currencies? The CPB were, in fact, forced to float their currencies in order not to lose the influential part of their foreign reserves on the aftermath of the economic crises. The decision to float came as the aftermath of the speculative attacks on the domestic currencies triggered by both the Asian crisis and external imbalances in their current accounts. The imbalances in the current accounts emerged as a result of pegging foreign exchange rates in conjunction with high domestic inflation, whereby a depreciation of the domestic currencies occurred.

4.3 IT is problematic in case the pass-through effect is higher; the problematic issue here being that the $\mathrm{CB}$, on the one hand, has to be credible with the announced target of inflation to make it serve as a nominal anchor for individuals' expectations. On the other hand, however, the CB may encounter a high effect of the exchange rate pass-through which may undermine the ability of the CB to achieve the inflation target. To be credible, the CB has to determine in advance escape clauses for its targets.

After Brazil was forced to float its currency (the real) in order not to lose an influential part of its foreign reserves under the pegging of the foreign exchange rates, the BCB was afraid of a higher level of the pass-through effect in the economy. The BCB estimated the pass-through effect at that time at 30-40 percent based of the estimated share of tradable goods in the economy. Although the pass-through effect was higher, the BCB did not explicitly continue targeting the foreign exchange rates but rather it announced its intention to apply an IT regime. The reason for the IT regime was that a nominal anchor for the monetary policy was essentially needed at that time to mitigate the panic in the economy (Fraga, 2000). In practice, the higher level of the pass-through effect led the BCB to, implicitly, target the exchange rate in an asymmetric way, i.e. by fighting devaluation and tolerating revaluation.

4.4 Missing inflation targets were generally referred to as forecast flaws. Although the escape clauses were defined explicitly in the case of the CNB (Czech Republic) and implicitly in the case of the NBP (Poland) ${ }^{8}$, the CBs in both the countries missed their inflation targets several times. In its assessment of ten years of IT, the CNB concluded that the forecast flaws were responsible for missing most of its targets (see Appendix 1). Although the NBP was less transparent regarding the real reasons behind the missing of

8 The stance of the NBP to shocks was defined to depend on the scale and duration of such shocks. The NBP does not respond to shocks which it deems temporary and which lie within the tolerance range around the target. Rather, the NBP responds to shocks which it views as leading to a permanent deviation from the inflation target (see Appendix 1). 
its targets, it took similar steps as the CNB to improve its forecasting ability by building more accurate and sophisticated models and improving its knowledge about monetary policy transmission mechanisms.

4.5 CB independence was factual. According to the aforementioned criterion of factual independence, the CBs in these countries possess legal instrument independence with an absence of both government representatives on the MPC as voting members and fiscal dominance in the form of formal obligation to the $\mathrm{CB}$ to finance budget deficits.

4.6 Factual independence of the CB mostly not granted by the government but assumed by the $C B$. The CBs, especially in the Czech Republic and Brazil, were the initiators proposing the IT regimes to the governments. Perhaps the CNB did not have to exert so much effort to convince the government of the adoption of an IT regime because the government was mainly motivated by the EU accession, but the BCB played an active role in convincing the government of the adoption of an IT regime.

\section{To what extent has Egypt satisfied prerequisites for an IT regime?}

This section explores whether Egypt has satisfied the aforementioned prerequisites for an IT regime in such a way that it makes the adoption of an IT regime in Egypt feasible to anchor individuals' expectations around the potential inflation targets. In this context I will exploit the experience of the CPB by comparing their positions in the early days of their adoption of IT regimes with the current position of Egypt. Such a comparison may enable us to assess whether Egypt is able to apply an IT regime or not.

The economic circumstances in Egypt in the 1990s were very similar to the comparison countries. The application of the economic reform program with the advent of the 1990s and the pegging of foreign exchange rates for long periods of time are the two common aspects between Egypt and the comparison countries. The main deference, however, was the reaction of the CBE to the economic crises that occurred in the second half of the 1990s. While the comparison countries reacted to the economic crises by floating their domestic currencies and adopting IT regimes, the CBE did not (see Appendix 3)9.

\section{The first prerequisite: factual independence of the CB}

As mentioned above, the factual independence of a $\mathrm{CB}$ rests on three basic pillars: (i) legal instrument independence of the CB; (ii) nonexistence of government representatives on the MPC as voting members; and (iii) absence of fiscal dominance including no obligation for the CB to finance budget deficits, while domestic financial markets should have enough depth to absorb placements of public debt such as treasury bills.

We may explore these elements for the CBE in light of Act no. 88 of the year 2003, amended by Act no. 162 of the year 2004 and Act no. 93 of the year 2005, known as the new laws on the $\mathrm{CB}$, the banking sector, and the money (henceforth, the new legislation $)^{10}$.

9 Appendix 3 includes details about the reasons that forced Egypt to float the FX rate. It is available upon request. 10 Available at: http://www.cbe.org.eg/public/Banking\%20Laws/Law\%2088,\%20amendments,\%2013-7-2005.pdf. 
(i) The legal independence of the CBE. Similar to the $\mathrm{CPB}$, the new legislation determined the primary objective of the monetary policy to be the achievement of the goal of price stability and banking system soundness within the context of the general economic policy of the state. In agreement with the government, the CBE sets the objectives of its monetary policy through a coordinating council formed by a Decree of the President of the Republic ${ }^{11}$.

The Governor of the CBE is appointed by a Decree of the President, upon his/her nomination by the Prime Minister, for a renewable term of four years, and is treated the same as a Minister in terms of his/her pension. The resignation of the Governor is accepted by a Decree of the President. The Governor has two Deputies appointed by a Decree of the President, upon their nomination by the Governor, for a renewable term of four years.

Like the CPB, the CBE possesses instrument independence, where the board of directors $(\mathrm{BoD})$, or MPC, of the $\mathrm{CBE}$ is the authority responsible for realizing the objectives of the monetary policy through implementing monetary, credit, and banking policies. The MPC also determines the instruments required to achieve the objectives; particularly, the instruments of monetary policy to be followed, the structure of credit and discount rates, the regulatory and supervisory standards to guarantee the soundness of the financial position of banks, and the regulation of auctions and tenders.

(ii) The government representatives in the MPC. Unlike the CPB, the MPC of the $\mathrm{CBE}$ includes government representatives as voting members. It consists of fourteen members, including two Deputy Governors, the chairman of the capital market authority, three members representing the Ministries of Finance, Planning and Foreign Trade, and eight experts in monetary, financial, banking, legal, and economic affairs designated by the President of the Republic for a renewable term of four years.

(iii) The obligation of the CBE to finance budget deficits. The CBE acts as a financial advisor and agent for the Government. Consequently, the CBE executes banking transactions pertaining to the Government and public legal persons, as well as internal and external finance with banks according to the conditions set by the MPC.

Unlike the other CBs of the CPB, the CBE has to extend finance to the Government, upon its request, to cover the seasonal deficit of the general budget, with an amount not in excess of $10 \%$ of the average revenues of the general budget in the three previous years. The term of such finance is three months renewable for other similar periods, with a maximum of twelve months. The conditions concerning such finance are determined upon agreement between the Ministry of Finance and the CBE. Also, the CBE has to guarantee the finance and credit facilities obtained by public legal persons from banks, financial institutions, and foreign or international institutions.

Moreover mparison between Egypt and the CPB in the early days of their adoption of IT regimes may shed some light on the position of Egypt relative to these countries, and highlight both the downsides and the benefits of the economic policy applied in Egypt.

11 The Coordinating Council for the Monetary Policy (CCMP), headed by the Prime Minister, composed of members, 6 of whom are independent of the private sector and international organizations; 3 from the CBE, and 3 Government Ministers. 
Table 1 exhibits some indicators of macroeconomic stability for both Egypt and the CPB. Both the inflation rate and the output growth rate in Egypt during the periods of 1995-1998 and 2005-2007 were better than those of the CPB during the period of 1995-1998. Also, the coefficient of variation (v) for both the inflation and the growth in Egypt during the period of 2005-2007 was better than that of the CPB during the period of 1995-1998.

Table 1

Some indicators of macroeconomic stability ${ }^{12}$

\begin{tabular}{|l|c|c|c|c|c|c|c|c|c|c|}
\hline \multirow{2}{*}{ Country } & \multirow{2}{*}{$\begin{array}{c}\text { Time of } \\
\text { adopting } \\
\text { IT }^{1}\end{array}$} & \multicolumn{2}{c|}{ CPI annual inflation } & \multicolumn{3}{c|}{ GDP growth rate } & \multicolumn{3}{c|}{$\begin{array}{c}\text { Real short-term } \\
\text { interest rate }\end{array}$} \\
\cline { 3 - 12 } & $\mathbf{M}$ & $\mathbf{S}$ & $\mathbf{V}$ & $\mathbf{M}$ & $\mathbf{S}$ & $\mathbf{V}$ & $\mathbf{M}$ & $\mathbf{S}$ & $\mathbf{V}$ \\
\hline $\begin{array}{l}\text { CZ } \\
(1995-1997)\end{array}$ & $\begin{array}{c}\text { December } \\
1997\end{array}$ & 8.84 & 0.31 & .035 & 3.05 & 3.41 & 1.12 & .95 & 4.1 & 4.31 \\
\hline $\begin{array}{l}\text { Poland } \\
(1995-1998)\end{array}$ & $\begin{array}{c}\text { March } \\
1999\end{array}$ & 18.63 & 7.07 & .379 & 6.25 & 0.95 & .152 & 5.85 & 7.65 & 1.3 \\
\hline $\begin{array}{l}\text { Brazil } \\
(1995-1998)\end{array}$ & $\begin{array}{c}\text { End of } \\
\text { June 1999 }\end{array}$ & 22.96 & 29.16 & 1.27 & 2.57 & 1.76 & .684 & 71.17 & 9.2 & .13 \\
\hline Average & & 16.81 & 12.18 & .56 & 3.95 & 2.04 & .65 & 26 & 6.98 & 1.9 \\
\hline Egypt (1995-1998) & 7.86 & 5.48 & .697 & 4.77 & 0.66 & .138 & 6.18 & 2.58 & .417 \\
\hline Egypt (2005-2007) & & 7.97 & 3.42 & .43 & 6.2 & 1.39 & .22 & - & - & - \\
\hline
\end{tabular}

$M=$ Mean, $S=$ Standard deviation, $V=$ Coefficient of variation $(S / M)$.

Source: The author: ${ }^{1}$ Appendix $1,{ }^{2}$ Calculated from Appendix 2, Table 2.3. The rest is calculated from Appendix 2, Table 2.1

Although the average rates of inflation in Egypt during both the periods of 1995-1998 and 2005-2007 were very similar, the rate of inflation during the latter period was ascendent and hit two-digit figures in mid-2007 according to the formal statistics (Appendix 2, Table 2.3). Theoretically, the higher of the rate of inflation and the lower of the rate of growth are more likely correlated with the adoption of an IT regime (Hu, Yifan, 2003). The high level of inflation rate in the CPB during the period of 1995-1998 and the reaction of their CBs by tightening their monetary policies explain the relatively high value of the coefficient of variation $(\mathrm{V})$ of the real interest rate in these countries compared with Egypt, where the rate of inflation was going down during the same period.

Table 2 deliver nother piece of information pertaining financial depth and symptoms of fiscal dominance. Williamson and Mahar (1998) suggest that financial depth, measured by M2/GDP, is a helpful indicator to determine a financial system's efficiency in mobilizing funds. According to this indicator, as shown in Table 2, Egypt exhibited better shape than the CPB even during the period of 1995-1998. Also, the claims on the government (annual growth as \% of M2) seem reasonable, comparable with Poland and much better than Brazil.

12 Tables 1-3 included in the text rest in some parts on the data included in Appendix 2. It is available upon request. 
Currently, the main shortcoming and the downside of the macroeconomic policy in Egypt is the performance of the general budget. Although the budget deficit (\% of GDP) in Egypt was reasonable, comparable with the CPB during the period of 1995-1998, it has been exacerbated during the successive periods after 2002 (see Table 3).

The higher ratio of the budget deficit in conjunction with both the existence of government representatives on the MPC and the legal obligation of the CBE to finance budget deficits represented the greatest danger for both the CBE's independence and the macroeconomic stability in Egypt.

Table 2

Some indicators of financial depth and symptoms of fiscal dominance

\begin{tabular}{|c|c|c|c|c|c|c|c|c|c|c|}
\hline \multirow[t]{2}{*}{ Country } & \multirow{2}{*}{$\begin{array}{l}\text { Time of } \\
\text { adopting } \\
\text { IT }^{1}\end{array}$} & \multicolumn{3}{|c|}{$\begin{array}{l}\text { Budget deficit } \\
\text { (\% of GDP) }\end{array}$} & \multicolumn{3}{|c|}{$\begin{array}{c}\text { Claims on the } \\
\text { government } \\
\text { (annual growth as \% of M2) }\end{array}$} & \multicolumn{3}{|c|}{$\begin{array}{c}\text { Financial depth = } \\
\text { M2 / GDP (\%) }\end{array}$} \\
\hline & & M & $\mathbf{S}$ & $\mathbf{V}$ & $\mathbf{M}$ & $\mathbf{S}$ & $\mathbf{V}$ & $\mathbf{M}$ & $\mathbf{S}$ & $\mathbf{v}$ \\
\hline $\begin{array}{l}\text { CZ } \\
(1995-1997\end{array}$ & $\begin{array}{c}\text { December } \\
1997\end{array}$ & 1.27 & .37 & .29 & -1.32 & 3 & -2.27 & 65.5 & 1.12 & .02 \\
\hline $\begin{array}{l}\text { Poland } \\
(1995-1998)\end{array}$ & $\begin{array}{c}\text { March } \\
1999\end{array}$ & - & - & - & 3.66 & 1.77 & .48 & 29.7 & 2.62 & .09 \\
\hline $\begin{array}{l}\text { Brazil } \\
(1995-1998)\end{array}$ & $\begin{array}{c}\text { End of } \\
\text { June } 1999\end{array}$ & .43 & .6 & 1.4 & 32.43 & 27.73 & .86 & 24.9 & .87 & .03 \\
\hline \multicolumn{2}{|l|}{ Average } & .85 & .48 & .84 & 11.6 & 10.83 & -.93 & 40 & 1.53 & .04 \\
\hline \multicolumn{2}{|c|}{ Egypt (1995-1998) } & 1.14 & .5 & .43 & 2.1 & 2.3 & 1.1 & 73.9 & 2 & .03 \\
\hline \multicolumn{2}{|c|}{ Egypt (2003-2007) } & $8.43^{4}$ & 1.07 & .12 & $3.77^{2}$ & .39 & .1 & $97.36^{3}$ & .7 & .001 \\
\hline
\end{tabular}

$M=$ Mean, $S=$ Standard deviation, $V=$ Coefficient of variation (S/M).

Source: The author: ${ }^{1}$ Appendix 1, ${ }^{2}$ Claims on the government for Egypt are calculated from Appendix 2, Table 2.4 for the period of 2003-2006, excluding 2005. 3 Financial depth for Egypt is calculated from Appendix 2, Table 2.4 for the period of 2003-2007. 4 Budget deficit for Egypt is calculated from Appendix 2, Table 2.3 for the period of $2005-2007$. The rest is calculated from Appendix 2, Table 2.2 for the period of 1995-1998.

Table 3

Banking system and CBE contributions to financing budget deficit in Egypt (2003-2007)

\begin{tabular}{|l|c|c|c|c|}
\hline Years & $\begin{array}{c}\text { Overall budget } \\
\text { deficit } \\
\text { (\% of GDP) }\end{array}$ & $\begin{array}{c}\text { Banking finance } \\
\text { to budget deficit } \\
\text { (\% of budget } \\
\text { deficit) }\end{array}$ & $\begin{array}{c}\text { CBE finance to } \\
\text { budget deficit } \\
\text { (\% of banking } \\
\text { finance) }\end{array}$ & $\begin{array}{c}\text { Public debt } \\
\text { (\% of GDP) }\end{array}$ \\
\hline 2003 & 10.4 & 44.3 & 26.6 & 60.4 \\
\hline 2004 & 9.5 & 45.8 & 112 & 60.3 \\
\hline 2005 & 9.6 & 60.8 & 78.88 & 64.84 \\
\hline 2006 & 8.2 & 29.37 & -77.44 & 62.77 \\
\hline 2007 & 7.5 & -38.25 & 15 & 65.4 \\
\hline Average & 9.1 & 28.41 & 31 & 63 \\
\hline
\end{tabular}

Source: Appendix 2, Table 2.3.

Table 3 mirrors the interaction among these factors. The high ratio of both the budget deficit and the public debt, averaging at $9.1 \%$ and $63 \%$ respectively for the period of 
2003-2007, were in conjunction with the high contribution of both the banking system and the CBE to financing the budget deficit. The contribution of the banking system was, on average, $45 \%$ of the overall budget deficit for the period of 2003-2006, while the involvement of the CBE in financing the budget deficit was, on average, 58\% of the banking system contribution during the same period of 2003-2007, excluding the year 2006.

To sum up, although the new legislation determined the primary objective of the monetary policy to be the achievement of the goal of price stability, and granted the CBE legal instrument independence, the existence of government representatives as voting members on the MPC and the coercion of the CBE to extend finance to the government are two elements sufficient to underpin any meaning of the de facto independence of the CBE. Consequently, the legal instrument independence granted to the CBE is sketchy and does not go beyond the de jure independence ${ }^{13}$. Moreover, although the comparison between Egypt and the Czech Republic, Poland, and Brazil came in favor of Egypt in many areas, the main shortcoming of the macroeconomic policy in Egypt is the performance of the general budget, including the high ratio of both budget deficit and public debt with a high contribution of the banking system and the CBE to financing it.

The second prerequisite: commitment to price stability as a primary goal of monetary policy

As mentioned above, a commitment to price stability requires two basic elements: (i) a CB should not target any other variables than the rate of inflation; and (ii) a CB should be transparent to the public about the exemptions of its inflation target, i.e., a CB should announce escape clauses for its inflation target. We explore these elements in the case of Egypt as follows.

(i) The CB should not target any other variables. The rationale behind this condition, as mentioned, is that targeting any other variables beside inflation is more likely to make the $\mathrm{CB}$ unable to achieve the inflation target either because of goals conflicting in the short run or because of the inflationary expectations induced by the uncertainty steaming from the lack of credibility of the CB in achieving the inflation targets.

As a threshold for switching from their monetary policy regimes to IT regimes, emerging market economies announced floating foreign exchange (FX) rates, although practically they applied a managed floating regime. Under the managed floating regime, a CB has an unannounced/implicit target for FX rates in the form of ranges within which the FX fluctuates. The CB intervenes on the FX market from time to time to return the FX rate back to the target. The reason that emerging market economies applied a managed and not a completely free floating regime may refer to the long history of FX turbulences in these countries, the volatility of international financial flows, and their vulnerability to FX rate shocks ${ }^{14}$. Therefore, managed

13 One of the tough critiques of the CCMP came from the Morgan Stanley report about the government, specifically the prime minister, overriding both the CCMP and the MPC of the CBE (Cevik, 2007).

14 In fact, all central banks occasionally exercise interventions on the FX markets even with announced free-floating FX rates. 
floating FX rates are intended to avoid the undesirable effects of FX rate volatility on both the real economy and the price level.

Why target FX rates implicitly not explicitly? In the experience of the $\mathrm{CPB}$, these countries were actually pegging foreign exchange rates but were forced to abandon that on the aftermath of the economic crises in order not to lose influential parts of their foreign reserves. After abandoning the pegging of the foreign exchange rates and floating domestic currencies, IT appeared to be the only available alternative to anchor individual expectations especially when it became clear that the association between money supply and prices had broken down. That is why many countries switched from their monetary policy regimes to IT regimes after floating the foreign exchange rates.

However, adopting an IT regime under the implicit targeting of FX rates may cause two problematic situations for the CB: The first is the case in which the domestic currency depreciates, especially when the pass-through effect is higher. In such a case the CB may increase the short-term nominal interest rate to return the FX rates back to the target. The increase in the short-term nominal interest rate may not lead to missing the inflation target if the forecasted level of inflation was higher than the targeted level. However, the CB may miss the inflation target if the forecasted level of inflation was lower than the targeted level. In this case, increasing the nominal interest rate to fix the depreciation of the domestic currency will cause undershooting the inflation target. The second problematic situation is the case in which the domestic currency appreciates. With the preliminary success of the CB in achieving the inflation target, the domestic inflation is turning down but, unfortunately, the domestic currency appreciates as well. One reason for such appreciation of the domestic currency is the convergence of both domestic and foreign inflation which lead the real exchange rates to increase (Holub, 2004). In such a case, the intervention of the CB by cutting the nominal interest rate to return the nominal exchange rates back to the target may not lead to missing the inflation target if the forecasted level of inflation was lower than the targeted level. However, the CB may miss the inflation target if the forecasted level of inflation was higher than the targeted level. In this case, cutting the nominal interest rate to fix the appreciation of the domestic currency will cause overshooting the inflation target.

Regarding Egypt, the question is: may the aforementioned scenario repeat in the case of Egypt, i.e., adopting an IT regime whereas implicitly targeting FX rates? Three reasons support the possibility that the behavior of the CBE will be similar to that of the majority of emerging market economies after the floatation of their currencies.

The first reason: The relationship between money and prices in Egypt has broken down. Consequently, after the decision to float FX rates the CBE is more likely to adopt an IT regime as an anchor for its monetary policy ${ }^{15}$.

The second reason: The FX rate regime in Egypt is not completely floating. After long periods of pegging FX rates and the insistence to maintain them despite

15 In a previous study, we assessed the efficiency of the currently applied monetary targeting regime in Egypt by measuring whether there is a relationship between money and prices, the stability of the velocity of circulation, and the stability of the demand for the money function. The results of the econometric study indicated that the relationship between money and prices in the Egyptian economy is loosened either in the short run or in the long run, the velocity of circulation is found nonstationary, there is no cointegration relationship between the money supply and the nominal GDP, and the long-term demand for the money function is not stable (Awad, 2008). 
the economic crises that occurred in the second half of the 1990s, the CBE was forced to float the FX rates after substantial losses of its foreign reserves (see Appendix 3). Although the foreign exchange rates are now unified and reasonably flexible, they are still dominating monetary policy decision-making in the CBE. Figure 1 clearly indicates that the change in the short-term nominal interest rates in the last periods (2006-2007) was oriented to adjusting the changes in the FX rates.

\section{Figure 1}

Interest rates and exchange rate during the period of 2003-2007

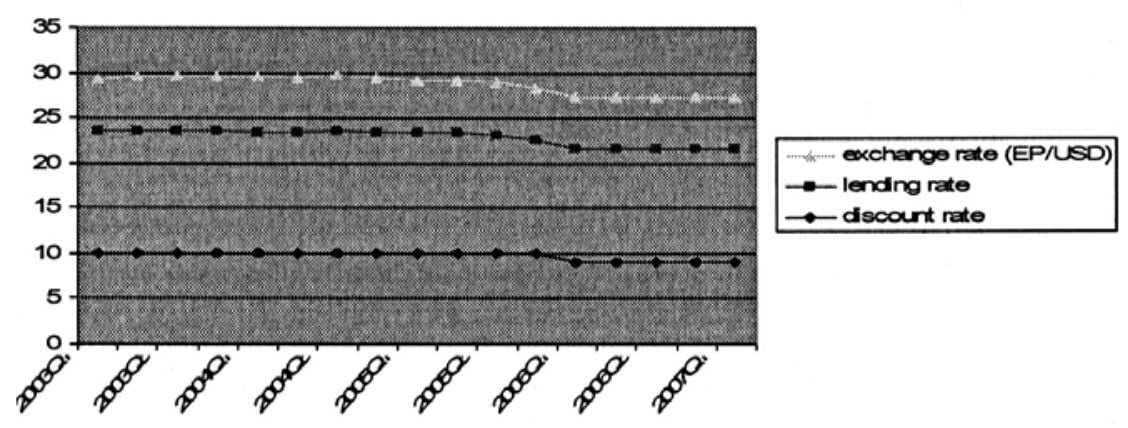

Source: Developed using data from IMF, IFS, CD-R, 2008.

The third reason: The pass-through effect in Egypt is high. Rabanal, 2005 (p. 4, p. 8) estimated the exchange rate pass-through effect in Egypt on both the wholesale price index (WPI) and the consumer price index (CPI) during the period of the exit from the pegging to the floatation of the FX rates, i.e., the period of 2000-2004. While the pass-through effect was higher on the WPI (from $30 \%$ to $60 \%$ ) and statistically significant, it was lower and not statistically significant for the CPI. The weak relationship between the exchange rate shocks and the changes in the CPI is referred to the relatively large share of goods with administrated prices included in the CPI series that was used until July 2003 (roughly one third to one half of the CPI items).

In total, the above reasons support the possibility that the behavior of the CBE, in the case of the adoption of an IT regime, will be similar to the behavior of the majority of emerging market economies, i.e., adopting an IT regime whereas implicitly targeting FX rates. Under this possibility, inflation targets are expected to be missed especially in the first stages of the application of the IT regime.

(ii) The CB should announce escape clauses for its inflation target. In the experience of the $\mathrm{CPB}$, not all of the CBs announced escape clauses for their inflation targets. While the BCB did not announce any escape clauses, the CNB preferred to be more transparent to the public by explicitly announcing the escape clauses, whereas the NBP did not explicitly announce any escape clauses but rather defined its stance from a shock depending on the scale and the duration of such a shock.

Although the BCB did not announce escape clauses, perhaps it pertained credibility for some reason; it used a relatively wide range: 2 percentage point tolerance interval around the central inflation target. Neither did the CNB announce escape clauses for its 
inflation targets in the early days of adopting an IT regime because during that period the CNB was targeting the so-called net inflation, which covers $80 \%$ from the CPI. The CNB announced the escape clauses immediately after abstaining from targeting the net inflation and the announcement in April 2001 of its intention to target the headline inflation measured by the CPI.

However, different alternatives are available to the CBE when it comes to the decision to adopt an IT regime: (i) explicitly announcing escape clauses, like in the case of the Czech Republic; (ii) defining shocks and determining the scale and the duration of a shock which will make the CB respond, like in the case of Poland; (iii) using a wide range for its inflation targets without announcing any escape clauses, like in the case of Brazil.

\section{The third prerequisite: forecasting capabilities}

In the experience of the $\mathrm{CPB}$, inflation targets were missed several times (see Appendix 1). Upon the explanation of the CNB regarding the decisive element behind the undershooting of the inflation targets, the non-fulfillment of inflation forecasts, owing to a combination of supply shocks and imperfections in the forecasting system, was the main element behind such undershooting.

As mentioned above, forecasting capabilities require three basic elements: (i) a model for inflation forecasting and inflation projections has to be in place; (ii) the $\mathrm{CB}$ has to have a clear idea about monetary policy transmission mechanisms and their associated lags; and (iii) inclusive, updated, and high-quality data have to be available.

To what extent are these elements currently available in Egypt? Regarding the first and second elements: Al-Mashat, 2008 (pp. 25-26) reported information about the status of inflation modeling and forecasting inside the CBE as shown in Table 4. Since this information is not available to any scholar in a normal way, then it raises a question regarding the degree of disclosure in the CBE, which is a cornerstone of a successful IT regime.

Moreover, the construction of the CPI core inflation by the CBE may serve as a useful tool for the MPC to follow up and evaluate the inflation behavior, but it will be risky if the $\mathrm{CBE}$ is planning to use it for the purpose of IT. As the CBE does not have a track record of credibility, the CPI core inflation or any other price index planned to be used for the purpose of IT has to be calculated by an independent entity, i.e., the CAPMAS in the case of Egypt.

However, even under the assumption that the information reported in Table 4 is corroborated, this information does not, in fact, reflect a satisfactory level of knowledge about some central issues that have to be tackled before the adoption of an IT regime. Such issues include the relationship between money supply and prices, the stability of the demand for the money function, the exchange rate pass-through effect, the level of the real exchange rate, the relative importance of monetary policy transmission channels and the associated time lags, the rate of inflation which should be targeted without causing an eruption of public debt, inflation forecasting, and inflation projections under different scenarios for supply and demand shocks. The CBE should have different models under different methodologies for each individual issue to compare and subtract accurate information. 
Table 4

Status of forecasting and modeling in the CBE

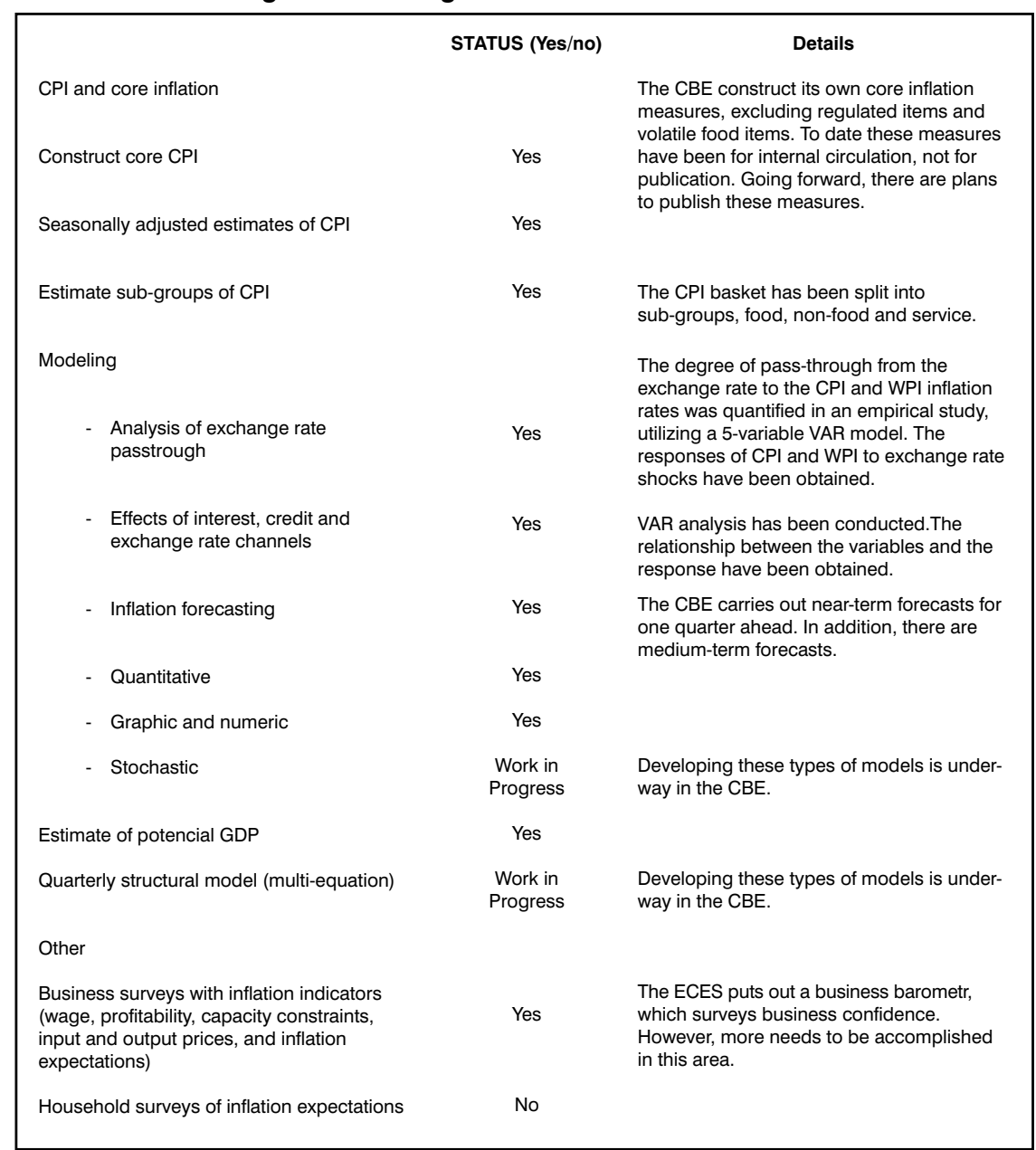

Source: Central Bank of Egypt (CBE) ${ }^{16}$

Regarding the third element: Using the Data Quality Assessment Framework (DQAF), the IMF (2005) assessed the quality of data in Egypt. Their assessment included the national accounts, the price indices, the government finance, the money, and the balance of payment statistics. Despite several shortcomings in many areas, the most defects in the Egyptian data were found in the accuracy and reliability, the serviceability, and the accessibility. The accuracy and reliability issue was mainly related to the national accounts and the price indices prepared by the Ministry of Planning (MOP) and the CAPMAS successively. The data serviceability issue included the fact that the dissemination of macroeconomic statistics does not in all cases fully meet the users' needs and there is no general oversight regarding the development and coordination of

16 CBE cited in Al-Mashat, 2008, p. 26 
macroeconomic statistics. The data accessibility issue included the difficulties of the availability of data among all interested parties equally and simultaneously.

\section{Conclusion}

The purpose of this study was to answer the question 'Is Egypt ready to apply an IT regime?' The study presumed that a country is ready to apply an IT regime once the prerequisites for an IT regime are met. The presumption of the study has been explored in the case of Egypt by answering the following questions: (i) what are prerequisites for an IT regime?; (ii) did emerging market economies satisfy the prerequisites for IT in the early days of their adoption of IT regimes?; and (iii) comparing the current position of Egypt to the emerging market economies in the early days of their adoption of IT regimes, has Egypt satisfied the prerequisites for an IT regime?

The conclusions of the study are as follows: (i) the CBE is not factually independent. Although the new legislation determined the primary objective of monetary policy to be the achievement of the goal of price stability and granted the CBE legal instrument independence, the existence of government representatives as voting members on the MPC and the coercion of the CBE to extend finance to the government are two elements sufficient to underpin any meaning of the de facto independence of the CBE. Moreover, the comparison between Egypt and the Czech Republic, Poland, and Brazil indicated that the main shortcoming of the macroeconomic policy in Egypt is the current performance of the general budget; (ii) there are many reasons in support of the possibility that the behavior of the CBE, in the event of the adoption of an IT regime, will be similar to the behavior of the majority of emerging market economies, i.e., adopting an IT regime whereas implicitly targeting FX rates. Under the possibility of this scenario, inflation targets are more likely to be missed especially in the first stages of the application of the IT regime; and (iii) the current level of knowledge of the CBE about some critical issues that have to be tackled before the adoption of an IT regime is not satisfactory and the quality of the currently available data is not likely to support the adoption of an IT regime.

In the light of these results, the study concludes that the fulfillment of prerequisites for an IT regime in Egypt is still unsatisfactory. Consequently, Egypt is still not ready to apply an IT regime.

\section{References}

Al-MASHAT, R. 2008. Monetary Policy in Egypt: A Retrospective and Preparedness of Inflation Targeting. Working Paper No. 134. ECES, 2008.

AWAD, I. L. 2008. Towards Measurement of Political Pressure on Central Banks: The case of the Central Bank of Egypt. Prague Economic Papers. 2008, vol. XVII, no. 3, s. 254-275.

AWAD, I. L. 2008. Switching to the Inflation Targeting Regime: The Case of Egypt (under publishing).

BATINI, N.; BREUER, P.; KOCHHAR, K.; SCOTT, R. 2006. Inflation Targeting and the IMF. [Online] Available at: http://www.imf.org/external/np/pp/eng/2006/031606.pdf [Accessed 10 November 2008].

BERNANKE, B.; WOODFORD, M. (eds.). 2005. The Inflation-Targeting Debate. Chicago; London : The University of Chicago Press, 2005. 
BERNANKE, B. S.; LAUBACH, T.; MISHKIN, F. S.; POSEN, A. S. 1999. Inflation Targeting: Lessons from the International Experience. Princeton; New Jersey : Princeton University Press, 1999.

CARARE, A.; SCHAECHTER, A.; STONE, M.; ZELMER, M. 2002. Establishing Initial Conditions in Support of Inflation Targeting. Working Paper, WP/02/102. IMF, 2002.

CBE 2005. Monetary Policy Statement. June 2, 2005 (English). [Online] Available at: http://www.cbe. org.eg/ [Accessed 15 November 2008].

CBE, 2007. Statement by the Central Bank of Egypt. [Online] Available at: http://www.cbe.org.eg/ [Accessed 10 November 2008].

CEVIK, S. 2007. When a prime minister makes monetary policy. Morgan Stanley report about Egypt. Available at: www.morganstanley.com/views/gef/archive/2007/20070328-Wed.html [Accessed 17 November 2008].

DEBELLE, G.; MASSON, P.; SAVASTANO, M.; SHARMA, S. 1998. Inflation Targeting as a Framework for Monetary Policy. Washington, DC : IMF,1998.

EICHENGREEN, B.; MASSON, P.; SAVASTANO, M.; SHARMA, S. 1999. Transition Strategies and Nominal Anchors on the Road to Greater Exchange-Rate Flexibility. International Finance. 1999, no. 213.

FRAGA, A. 2000. Monetary Policy during the Transition to a Floating Exchange Rate: Brazil's Recent Experience. Finance \& Development. 2000, vol. 37, no. 1, March.

FRAGA, A.; GOLDFAJN, I.; MINELLA, A. 2003. Inflation targeting in Emerging Market Economies. Working Paper No. 10019. NBER, 2003.

HU, YIFAN. 2003. Empirical Investigations of Inflation Targeting. WP/03/6.

IMF. 2005. Arab Republic of Egypt: Report on the Observance of Standards and Codes-Data Module. IMF Country Report No. 05/238. Washington, DC : IMF, 2005.

IMF. 2007. Arab Republic of Egypt: Selected Issues. IMF country report No. 07/381. Washington, $D C$ : IMF, December 2007.

JONAS, J.; MISHKIN, F. S. 2003. Inflation Targeting in Transition Countries: Experience and Prospects. Working Paper 9667. NBER, 2003.

KHAN, M. S. 2003. Current Issues in the Design and Conduct of Monetary Policy. Working Paper, WP/03/56. IMF, 2003.

MASSON, P. R.; SAVASTANO, M. A.; SUNIL SHARMA. 1998. Can Inflation Targeting Be a Framework for Monetary Policy in Developing Countries? Finance \& Development. [Online] Available at: http://www.imf.org/external/pubs/tt/fandd/1998/03/pdf/masson.pdf [Accessed 17 November 2008].

MISHKIN, F. S. 2000. Inflation Targeting in Emerging Market Countries. Working Paper No. 7618. NBER, 2000.

MISHKIN, F. S.; SCHMIDT-HEBBEL, K. 2001. One Decade of Inflation Targeting in the World: What Do We Know and What Do We Need to Know? Working Paper No. 8397. NBER, 2001.

Oxford Analytica. 2005. Egypt: Monetary Transparency, Country Report, November 2005. [Online] Available at: http://www.calpers.ca.gov/eipdocs/investments/assets/equities/international/permissible/ egypt-monetary-report.pdf [Accessed 15 November 2008].

RABANAL, P. 2005. Arab Republic of Egypt: Selected Issues. IMF Country Report No. 05/179. Washington, DC : IMF, June 2005.

SCHMIDT-HEBBEL, K.; TAPIA, M. 2002. Monetary Policy Implementation and Results in Twenty Inflation-Targeting Countries. Working Papers No. 166. Central Bank of Chile, 2002.

TRUMAN, E. M. 2003. Inflation Targeting in the World Economy. Washington, DC : Institute for International Economics, 2003.

WILLIAMSON, J.; MAHAR, M. 1998. A Survey of Financial Liberalization. International Finance. 1998, no. 211. 


\title{
DID EGYPT SATISFY PREREQUISITES FOR AN IT REGIME?
}

\begin{abstract}
The purpose of this study is to answer the question 'Is Egypt ready to apply an IT regime?' The study presumed that a country is ready to apply an IT regime once the prerequisites for an IT regime are met. Comparing the current position of Egypt with some emerging market economies, the conclusions of the study are as follows: (i) the CBE is not factually independent. Although the CBE has been granted legal instrument independence, the existence of government representatives as voting members on the MPC and the coercion of the CBE to extend finance to the government are two elements sufficient to undermine the de facto independence of the CBE; (ii) inflation targets are expected to be missed under the possibility that the behavior of the CBE will be similar to the behavior of the majority of emerging market economies, i.e., adopting an IT regime whereas implicitly targeting FX rates; and (iii) the current level of knowledge about some central issues of designing an IT regime and the quality of the available data are not satisfactory to support the adoption of an IT regime. The study concludes that Egypt is still not ready to apply an IT regime.
\end{abstract}

Keywords: Inflation targeting regime; Prerequisites for an inflation targeting regime; Inflation targeting in Egypt

JEL Classification: E500, E580, E600 